\title{
PERBANDINGAN HASIL BELAJAR MENGGUNAKAN MODEL PEMBELAJARAN TPS DAN TPT SMAN 1 PALLANGA KABUPATEN GOWA
}

\author{
Abudzar Ghifari \\ Jurusan Pendidikan Biologi Fakultas Tarbiyah dan Keguruan, \\ UIN Alauddin Makassar, Kampus II Jl. H. M. Yasin Limpo No. 36 \\ Samata-Gowa, Sulawesi Selatan 92118, Telepon: (0411) 424835 \\ E-mail: abudzarghifari_albasyar@yahoo.co.id \\ Andi Maulana \\ Jurusan Pendidikan Biologi Fakultas Tarbiyah dan Keguruan, \\ UIN Alauddin Makassar, Kampus II Jl. H. M. Yasin Limpo No. 36 \\ Samata-Gowa, Sulawesi Selatan 92118, Telepon: (0411) 424835 \\ E-mail: maulanaandi.1962@yahoo.com \\ Thamrin Tayeb \\ Jurusan Pendidikan Biologi Fakultas Tarbiyah dan Keguruan, \\ UIN Alauddin Makassar, Kampus II Jl. H. M. Yasin Limpo No. 36 \\ Samata-Gowa, Sulawesi Selatan 92118, Telepon: (0411) 424835 \\ E-mail: Thamrin tayeb@yahoo.com
}

\begin{abstract}
Abstrak
Penelitian ini membahas model pembelajaran kooperatif yaitu Think Pair Share dan The Power of Two pada pokok bahasan Sistem Pencernaan Siswa Kelas XI SMA Negeri 1 Pallangga. Dengan tujuan penelitian untuk mengetahui apakah terdapat perbedaan hasil belajar siswa yang diajar dengan model pembelajaran koopertaif Think Pair Share dan The Power of Two pada pokok bahasan Sistem Pencernaan siswa kelas XI SMA Negeri 1 Pallangga. Penelitian ini merupakan penelitian eksperimen bentuk Quasi Experimental Design (eksperimen semu) desain penelitian yang digunakan adalah Posttest-Only Control Design. Populasi penelitian adalah seluruh siswa kelas XI SMA Negeri 1 Pallangga. Sampel penelitian yaitu kelas XI IPA4 sebagai eksperimen I dan kelas XI IPA7 sebagai eksperimen II. Pengambilan data dilakukan dengan menggunakan tes hasil belajar yang berupa Posttest, observasi dan dokumentasi. Data yang diperoleh dianalisis dengan menggunakan teknik analisis deskriptif dan teknik analisis inferensial. Analisis data menunjukan hasil belajar siswa Kelas XI SMA Negeri 1 Pallangga pada pokok bahasan Sistem Pencernaan yang diajar melalui model pembelajaran kooperatif Think Pair Share dan The Power of Two. Pertama, hasil belajar peserta didik yang diajar melalui model pembelajaran kooperatif Think Pair Share berada pada kategori rendah dengan persentase $41,4 \%$ dari 39 peserta didik dan nilai ratarata sebesar 54,25. Kedua, hasil belajar peserta didik yang diajar melalui model pembelajaran kooperatif The Power Of Two belajar berada pada kategori tinggi dengan persentase $70 \%$ dari 30 peserta didik dengan nilai rata-rata sebesar 66,88 . Ketiga dari hasil analisis uji hipotesis menggunakan uji- $t$ diperoles nilai $t h i t=4,87$ dan nilai $t_{t a b}=1,67$. Dimana nilai thit $>$ tab sehingga $H_{0}$ ditolak, $H_{1}$ diterima, dengan demikian terdapat perbedaan rata-rata hasil belajar peserta didik yang
\end{abstract}


diajar melalui model pembelajaran kooperatif tipe Think Pair Share dan tipe The Power Of Two pada pokok Sistem Pencernaan kelas XI SMA Negeri 1 Pallangga Kabupaten Gowa.

Kata Kunci: Hasil Belajar Biologi, TPS, TPT

\begin{abstract}
This thesis discusses cooperative learning model that Think Pair Share and The Power of Two on the subject of the Digestive System Student Class XI SMAN 1 Pallangga. With the aim of research to find out whether there are differences in learning outcomes of students who are taught by koopertaif learning model Think Pair Share and The Power of Two on the subject of the digestive system of class XI student of SMAN 1 Pallangga. This research is experimental form of Quasi Experimental Design (quasi-experimental) design study is a "Posttest-Only Control Design". The study population was all students of class XI SMA Negeri 1 Pallangga. The research sample is class XI IPA4 as an experiment I and class II XI IPA7 as an experiment. Data collection was performed by using the test results in the form posttest study, observation and documentation. Data were analyzed using descriptive analysis techniques and inferential analysis techniques. Analysis of the data shows the results of student learning Class XI SMAN 1 Pallangga on the subject of the digestive system that is taught through cooperative learning model Think Pair Share and The Power of Two. First, the study of students who were taught through cooperative learning model Think Pair Share is in the low category with a percentage of $41.4 \%$ of 39 students and an average value of 54.25. Second, the study of students who were taught through cooperative learning model The Power of Two learning at high category with a percentage of $70 \%$ of the 30 students with an average value of 66.88. All three of the analytical results of hypothesis testing using $t$-test, thit value $=4.87$ and $t_{\text {tab }}$ value $=1.67$. Where the value of $t_{\text {hit }}>t_{\text {tab }}$ so $H_{0}$ rejected, $H_{1}$ accepted, thus there are differences in the average learning outcomes of students who were taught through cooperative learning model Think Pair Share and types The Power of Two on the subject of the digestive system of class XI SMA Negeri 1 Pallangga Gowa.
\end{abstract}

Keywords: Biology Learning Outcomes, TPS, TPT

\title{
PENDAHULUAN
}

Salah satu masalah yang dihadapi dunia pendidikan adalah masalah lemahnya proses pembelajaran. Proses pembelajaran, anak kurang didorong untuk mengembangkan kemampuan berpikir. Proses pembelajaran di dalam kelas diarahkan kepada kemampuan anak untuk menghafal informasi, otak anak dipaksa untuk mengingat dan menimbun berbagai informasi tanpa dituntut untuk memahami informasi yang diingatnya itu untuk menghubungkannya dengan kehidupan sehari-hari. Akibatnya, ketika peserta didik lulus dari sekolah, mereka pintar secara teoritis, akan tetapi mereka miskin aplikasi (Sanjaya 2009, 1).

Belajar merupakan proses dalam diri individu yang berinteraksi dengan lingkungan untuk mendapatkan perubahan dalam perilakunya. Belajar adalah aktivitas 
mental/psikis yang berlangsung dalam interaksi aktif dengan lingkungan yang menghasilkan perubahan perubahan dalam pengetahuan, keterampilan dan sikap. Perubahan itu diperoleh melalui usaha (bukan karena kematangan), menetap dalam waktu yang relatif lama dan merupakan hasil pengamatan (Purwanto, 2013: 39).

Hasil belajar siswa merupakan prestasi yang telah dicapai dari proses belajar. Baik buruknya hasil belajar tersebut tergantung bagaimana proses belajar berlangsung dan tanggapan siswa dari proses tersebut. Apabila proses tersebut berlangsung seperti yang diharapkan tanpa ada gangguan baik internal atau eksternal siswa maka hasil belajar akan berhasil seperti yang diharapkan, dan sebaliknya kalau terdapat gangguan maka hasilnya pun jauh dari harapan.

Permasalahan yang dihadapi dalam proses pembelajaran pada observasi awal, dalam kegiatan belajar sebagian peserta didik masih sering berbicara sendiri dengan teman sebangkunya saat kegiatan pembelajaran berlangsung sehingga dapat mengganggu para peserta didik lainnya. Selain itu, setiap pendidik mengajukan pertanyaan dijawab dengan serempak, hal ini menunjukkan tidak adanya kepercayaan diri pada peserta didik untuk mengungkapkan pendapatnya.

SMA Negeri 1 pallangga merupakan salah satu lembaga pendidikan yang mengemban tugas mencerdaskan kehidupan bangsa, untuk selanjutnya berupaya menyelaraskan kualitas dan lembaga pendidikan lainnya, meskipun upaya tersebut telah dilakukan namun kenyataannya masih terdapat banyak kekurangan yang harus dibenahi, kekurangan yang paling mendasar dan sangat dirasakan pada pendidikan formal (sekolah) dewasa ini adalah masih rendahnya daya serap peserta didik. Hal ini tampak pada prestasi belajar peserta didik yang senantiasa masih rendah.

Model pembelajaran kooperatif yang akan diterapkan oleh peneliti di sekolah tersebut ada dua macam, yaitu Think Pair Share (TPS) dan The Power of Two (TPT). Beberapa penyebab yang melatar belakangi peneliti sehingga memilih metode tersebut adalah karena ke dua metode tersebut sama-sama memfokuskan keaktifan peseta didik di kelas daripada model pembelajaran yang berlaku sebelumnya. Selain itu kedua metode tersebut lebih mudah dan sederhana dipahami oleh peserta didik kelas berapa saja, dalam menyajikan suatu materi yang membutuhkan kesediaan peserta didik untuk lebih aktif dalam memahami pelajaran yang diajarkan di dalam kelas. Kedua pembelajaran tersebut memberikan kesempatan kepada peserta didik untuk berkreatifitas dan bertanya jawab kepada pendidik dan teman kelasnya, sehingga kejenuhan dan kebosanan dalam belajar menjadi lebih menyenangkan.

Sistem Pencernaan adalah salah satu pokok bahasan pada siswa SMA Negeri 1 Pallangga kelas XI IPA Kabupaten Gowa, bahasan tersebut membutuhkan metode pembelajaran yang dapat dengan mudah dicerna baik oleh peserta didik. Pokok bahasan yang luas, menuntut materi ini harus dijelaskan dan diajarkan kepada siswa secara kreatif dan inovatif, agar peserta didik tidak merasa bosan dan keinginannya untuk belajar menjadi lebih baik daripada sebelumnya. 
Berdasarkan uraian di atas, perlu adanya model pembelajaran alternatif yang berdasar kepada kebersamaan yang disebut dengan pembelajaran kooperatif (cooperative learning). Hal yang mendasari model pembelajaran ini berdasar pada falsafah yang mengatakan manusia merupakan makhluk sosial, tanpa adanya kerja sama tidak akan adanya individu, keluarga, organisasi, atau sekolah. Tanpa kerja sama kehidupan ini tentulah sudah punah, oleh karena itu peneliti mencoba melakukan penelitian yang mengangkat judul "Perbandingan Hasil Belajar Menggunakan Model Pembelajaran Kooperatif Tipe TPS dan Tipe TPT Pada Materi Sistem Pencernaan Siswa Kelas XI SMA Negeri 1 Pallangga Kabupaten Gowa”.

\section{METODOLOGI PENELITIAN}

Penelitian ini adalah penelitian Quasi Eksperimen, dengan pendekatan kuantitatif. Penelitian Quasi Eksperimen ini bertujuan untuk mengetahui ada tidaknya pengaruh dari perlakuan yang diberikan terhadap objek yang diteliti (Suryabrata Sumadi 2009, 92). Desain penelitian yang digunakan adalah The Static Post-test Design. Desain Post Test Only Control Design adalah suatu pola post-test desain dimana peneliti tidak terlalu mengharapkan adanya keseragaman hasil yang diperoleh oleh siswa atau responden yang dites (Sugiyono 2011, 121). Penelitian ini dilakukan pada kelas XI IPA di SMA Negeri 1 Pallangga tahun pelajaran 2015/2016 yang jumlahnya 307 orang. Teknik pengambilan sampel yang digunakan adalah Simple Random Sampling, dikatakan simple (sederhana) karena pengambilan anggota sampel dari populasi dilakukan secara acak tanpa memperhatikan strata yang ada dalam populasi itu. Cara demikian dilakukan bila anggota populasi dianggap homogen (Sugiyono 2013, 120).

Instrumen penelitian digunakan untuk mengukur nilai variabel yang diteliti. Jumlah instrumen penelitian tergantung pada jumlah variabel penelitian yang telah ditetapkan untuk diteliti (Sugiyono 2013, 92). Adapun instrumen yang digunakan dalam penelitian yaitu: (1) Tes hasil belajar, (2) Lembar Observasi meliputi guru dan siswa, dan (3) Dokumentasi. Pengolahan data hasil penelitian digunakan dua teknik statistik, yaitu statistic deskriptif dan statistik inferensial.

\section{HASIL PENELITIAN DAN PEMBAHASAN}

\section{Deskripsi Hasil Belajar Biologi Yang Menggunakan Model Pembelajaran Kooperatif Tipe Think Pair Share (TPS)}

Berdasarkan analisis deskriptif hasil posttest pada kelas eksperimen I diperoleh nilai hasil belajar (posttest) kelas eksperimen I setelah diberikan posttest, yakni nilai rata-rata posttest adalah 54,25. Pada hasil belajar (posttest) kelas eksperimen I tidak terdapat siswa yang kategori hasil belajar (posttest) kelas eksperimen I sangat rendah dan sangat tinggi atau dapat dikatakan bahwa $0 \%$ siswa tidak terdapat pada kategorisasi sangat rendah dan sangat tinggi, terdapat 12 siswa berada pada kategori rendah dengan persentase $41,4 \%$, pada kategori sedang terdapat 9 siswa dengan persentase $31 \%$, 
sedangkan pada kategori tinggi kita dapat melihat bahwa terdapat 8 siswa dengan persentase sebesar $27,6 \%$.

Tabel 1. Nilai Hasil Belajar (Posttest) Kelas Eksperimen I Dengan Model Pembelajaran Kooperatif Think Pair Share (TPS)

\begin{tabular}{llc}
\hline No & Nama & Nilai Post Test \\
\hline 1. & Nur hikmah & 62 \\
2. & Firda & 50 \\
3. & Zalzabila Pratiwi & 58 \\
4. & Suerni & 41 \\
5. Nur Halima Nurdin & 65 \\
6. & Andre Suandi & 67 \\
7. & Nur Jannah & 55 \\
8. & Nur Fadilah & 70 \\
9. Ilda Nurfadhilah & 67 \\
10. Muh Zulkifli & 45 \\
11. Sri Wahyuni S & 46 \\
12. Rini Anriyani & 40 \\
13. Al Muhajir & 60 \\
14. Chaerul Hendra & 35 \\
15. Riskayana & 35 \\
16. Irdayanti & 57 \\
17. Nurul Ramadanti & 55 \\
18. Widiya May Astuti & 40 \\
19. Muh Nur Ikhsan & 56 \\
20. Elvira Eka Wahyuni & 50 \\
21. Yulinar & 68 \\
22. Reski Ananda & 52 \\
23. Nur Khalisa M & 70 \\
24. Nurul Fahmi Syam & 70 \\
25. Nur Alisa R & 62 \\
26. Muh Gilang Eka Putra & 45 \\
\hline & &
\end{tabular}

Berdasarkan hasil penelitian yang telah dilakukan pada kelas XI IPA 4 SMA Negeri 1 Pallangga yang ditetapkan sebagai kelas eksperimen I yang menggunakan model pembelajaran kooperatif tipe TPS dalam proses belajar mengajar, setelah dilakukan pengujian analisis statistic deskripsi diperoleh data bahwa hasil belajar posttest siswa XI IPA 4 SMA Negeri 1 Pallangga dengan jumlah 30 soal pilihan ganda yang berkaitan dengan mata pelajaran biologi pokok bahasan Sistem Pencernaan, maka diperoleh nilai rata-rata yang diperoleh dan dijadikan sebagai acuan dalam 
pengkategorian adalah 54,25, dimana jumlah pesesrta didik dengan kategori sangat rendah sebanyak 0\%, artinya tidak ada peserta didik dalam kategori ini, rendah sebanyak 12 siswa dengan persentase 41,4\%, sedang sebanyak 9 siswa dengan persentase sebesar $31 \%$, tinggi sebanyak 8 siswa dengan persentase sebesar $27,6 \%$ dan pada kategori sangat tinggi tidak ada siswa yang berada pada kategori tersebut dengan persentase sebesar $0 \%$.

Dengan demikian hasil belajar posttest siswa kelas XI IPA4 yang diajar melalui model pembelajaran TPS berada pada kategori rendah dengan persentase $41,4 \%$. Hal tersebut sejalan dengan penelitian yang telah dilakukan oleh Yahya (2012), yang menyatakan bahwa dengan menggunakan model pembelajaran kooperatif tipe TPS dapat meningkatkan hasil belajar karena dengan menggunakan model tersebut siswa dapat terlibat secara aktif dalam proses pembelajaran dan mereka juga diajarkan untuk menghargai pendapat yang diutarakan oleh temannya serta memupuk kerja yang baik antar siswa.

\section{Deskripsi Hasil Belajar Biologi Yang Menggunakan Model Pembelajar Kooperatif Tipe The Power Of Two (TPT)}

Nilai terendah yang diperoleh pada kelas eksperimen II adalah 51 dan nilai tertinggi adalah 78. Nilai rata-rata yang diperoleh adalah 66,88 dengan standar deviasinya adalah 75,318 dan koefisien variansi relatif 12,97\%. Berdasarkan analisis deskriptif hasil posttest pada kelas eksperimen II diperoleh nilai hasil belajar (posttest) kelas eksperimen II setelah diberikan posttest, yakni nilai rata-rata posttest adalah 66,88.

Dari pengolahan data diatas maka dapat diketahui thitung $=4,87$ dan harga ttabel dengan $\alpha=0,05$ dan $\mathrm{dk}=(30+29-2)=57$ adalah 1,67. Sehingga $t_{\text {hitung }}>\mathrm{t}_{\text {tabel }}(4,87$ $>1,67)$. Jika thitung $>$ ttabel maka $\mathrm{H}_{0}$ ditolak dan $\mathrm{H}_{1}$ diterima, berarti terdapat perbedaan signifikansi. Sehingga dapat disimpulkan jika thitung $=4,87$ lebih besar daripada nilai $t_{\text {tabel }}=1,67$, bahwa bahwa $\mathrm{H}_{0}$ ditolak dan $\mathrm{H}_{1}$ diterima atau terdapat perbedaan yang signifikan antara rata-rata nilai hasil belajar kelas XI IPA4 (eksperimen I) yang diberi perlakuan model pembelajaran kooperatif tipe TPS dan rata-rata hasil belajar nilai kelas $\mathrm{XI} \mathrm{IPA}_{7}$ (eksperimen II) yang diberi perlakuan model pembelajaran kooperatif tipe TPT.

Berdasarkan hasil penelitian yang telah dilakukan pada kelas XI IPA SMA Negeri 1 Pallangga yang ditetapkan sebagai kelas eksperimen II yang menggunakan model pembelajaran kooperatif tipe TPT dalam proses belajar mengajar, setelah dilakukan pengujian analisis statistik deskripsi diproleh data bahwa hasil belajar posttest siswa XI $\mathrm{IPA}_{7}$ SMA Negeri 1 Pallangga dengan jumlah 30 soal pilihan ganda yang berkaitan dengan mata pelajaran biologi pokok bahasan Sistem Pencernaan, maka diperoleh nilai rata-rata yang diperoleh dan dijadikan sebagai acuan dalam pengkategorian adalah 66,88 . 
Tabel 2. Nilai Hasil Belajar (Posttest) Kelas Eksperimen 2 Dengan Model Pembelajaran Kooperatif The Power Of Two (TPT)

\begin{tabular}{|c|c|c|}
\hline No & Nama & Nilai Post Test \\
\hline 1. & A Rifdah Mutaharah & 64 \\
\hline 2. & Alfiandi & 75 \\
\hline 3. & Alvira & 75 \\
\hline 4. & Rahmawati B & 51 \\
\hline 5. & Harismawati & 78 \\
\hline 6. & Wahyuni & 73 \\
\hline 7. & Rahmiyati & 73 \\
\hline 8. & Wulan Mawardika & 54 \\
\hline 9. & Achmad Arham A & 75 \\
\hline 10. & Asdiani & 70 \\
\hline 11. & Haspina Hasan & 59 \\
\hline 12. & Firawati & 71 \\
\hline 13. & Misnawati & 71 \\
\hline 14. & Rahmawati J. & 56 \\
\hline 15. & Muh Ulil Amri & 61 \\
\hline 16. & Nindyah Ariyani Azzahrah Ridwan & 53 \\
\hline 17. & Audrion Maulana R & 51 \\
\hline 18. & Febriyanti Nugrahayu & 61 \\
\hline 19. & St Sulaeha & 73 \\
\hline 20. & Ardiyansah & 73 \\
\hline 21. & Andi Supriadi & 78 \\
\hline 22. & Nurul Hasbi & 59 \\
\hline 23. & Adinda Lutfiah Hermawan & 63 \\
\hline 24. & Rostia & 51 \\
\hline 25. & Muh Nur Rahmat Saleh & 75 \\
\hline 26. & Muh Arman & 64 \\
\hline 27. & Indah Wulandari & 76 \\
\hline 28. & Muh Ghalib & 75 \\
\hline 29. & Satrio Widodo D & 63 \\
\hline 30. & Muh Asmin & 78 \\
\hline
\end{tabular}

Dari jumlah tersebut, peserta didik dengan kategori sangat rendah sebanyak 0\%, artinya tidak ada peserta didik dalam kategori ini, rendah sebanyak 5 siswa dengan persentase $16,7 \%$, sedang sebanyak 4 siswa dengan persentase sebesar 13,3\%, tinggi sebanyak 21 siswa dengan persentase sebesar $70 \%$ dan pada kategori sangat tinggi tidak ada siswa yang berada pada kategori tersebut dengan persentase sebesar 0\%. Dengan 
demikian hasil belajar posttest kelas XI IPA7 yang diajar melalui model pembelajaran kooperatif tipe TPT berada pada kategori tinggi dengan persentase $70 \%$.

Hal tersebut sejalan dengan penelitian yang telah dilakukan oleh Rahayu (2011), yang menyatakan bahwa dengan menggunakan model pembelajaran kooperatif tipe TPT dapat meningkatkan kemampuan berfikir dan kemampuan mencari sendiri jawaban yang telah diberikan yang berkaitan dengan materi yang telah dipelajarinya, dan dapat menumbuhkan sikap menghargai pendapat dan kerja sama yang baik antara teman kelompoknya.

\section{Tingkat Perbandingan Hasil Belajar Biologi Peserta Didik yang Menggunakan Model Pembelajaran Kooperatif Tipe Think Pair Share (TPS) dan Model Pembelajaran Kooperatif Tipe The Power Of Two (TPT)}

Pada pengujian hipotesis dengan menggunkan uji t-test sampel independen, dimana data yang di uji yaitu hasil posttest kedua kelompok. Berdasarkan hasil pengolahan secara manual diperoleh nilai thitung untuk nilai posttest adalah 4,87 dengan menggunakan taraf signifikansi $5 \%$ atau $=0,05$ dan dengan derajat kebebasan 57 , diperoleh hasil thitung sebesar 1,67 . Karena $t_{\text {hitung }}>t_{\text {tabel }}(4,87>1,67)$ maka $\mathrm{H}_{0}$ ditolak dan $\mathrm{H}_{1}$ diterima.

Dalam artian bahwa terdapat perbedaan signifikansi. Sehingga dapat disimpulkan thitung $=4,87$ lebih besar daripada nilai tabel $=1,67$, maka $\mathrm{H}_{0}$ ditolak dan $\mathrm{H}_{1}$ diterima atau terdapat perbedaan yang signifikan antara rata-rata nilai kelas XI IPA4 (eksperimen I) yang diberi perlakuan model pembelajaran kooperatif tipe TPS dan rata-rata nilai kelas XI IPA7 (eksperimen II) yang diberi perlakuan model pembelajaran kooperatif tipe TPT.

Model pembelajaran kooperatif tipe TPS merupakan salah satu model pembelajaran yang membentuk kelompok diskusi secara berpasangan. Model pembelajaran ini memiliki beberapa kelebihan, diantaranya mengembangkan potensi siswa dalam mengemukakan pendapat. Sedangkan, model pembelajaran kooperatif tipe TPT juga salah satu model pembelajaran yang membentuk kelompok diskusi secara berpasangan. Kelebihan dari model pembelajaran ini diantaranya dapat mengembangkan kemampuan mengungkapkan ide atau gagasan serta membantu siswa agar dapat bekerjasama dengan orang lain (teman sebangkunya).

Hal ini sejalan dengan pendapat Mafatih dan Bisyiri (2013), bahwa trategi belajar kekuatan berdua (The Power Of Two) termasuk bagian dari belajar kooperatif adalah belajar dalam kelompok kecil dengan menumbuhkan kerja sama secara maksimal melalui kegiatan pembelajaran oleh teman sendiri dengan anggota dua orang di dalamnya untuk mencapai kompetensi dasar. Selain itu menurut Huda (2013), model Pembelajaran TPS atau Berpikir-berpasangan-berbagi, merupakan model pembelajaran yang dikembangkan oleh Frank Lyman yang memungkinkan siswa untuk bekerja sendiri dan bekerja sama dengan orang lain, mengoptimalkan partisipasi siswa, mampu memberikan kesempatan setidaknya delapan kali lebih banyak kepada setiap siswa 
untuk menunjukkan partisispasi mereka kepada orang lain serta model ini biasa diterapkan untuk semua mata pelajaran dan tingkatan kelas.

\section{KESIMPULAN}

Berdasarkan hasil penelitian dan pembahasan sebelumnya, maka diperoleh beberapa kesimpulan sebagai berikut:

1. Hasil belajar posttest yang telah dilakukan pada kelas XI IPA 4 SMA Negeri 1 Pallangga sebagai kelas eksperimen I menggunakan model pembelajaran kooperatif tipe Think Pair Share (TPS) diperoleh nilai rata-rata adalah 54,25. Nilai hasil belajar siswa kelas XI IPA4 yang diajar melalui model pembelajaran Think Pair Share (TPS) berada pada kategori rendah dengan persentase $41,4 \%$.

2. Hasil belajar posttest yang telah dilakukan pada kelas XI IPA 7 SMA Negeri 1 Pallangga sebagai kelas eksperimen II menggunakan model pembelajaran kooperatif tipe The Power of Two (TPT) diperoleh nilai rata-rata adalah 66,88. Nilai hasil belajar siswa kelas XI IPA7 yang diajar melalui model pembelajaran The Power Of Two (TPT) berada pada kategori tinggi dengan persentase 70\%.

3. Terdapat perbedaan hasil belajar biologi antara kelompok siswa yang diajar dengan menggunakan model pembelajarn kooperatif tipe Think Pair Share (TPS) dengan kelompok siswa yang diajar dengan menggunakan model pembelajaran kooperatif tipe The Power of Two (TPT) pada pokok bahasan sistem pencernaan siswa kelas XI SMA Negeri 1 Pallangga Kabupaten Gowa. Hal tersebut dapat dilihat dari analisis inferensial pada pengujian hipotesis dengan menggunkan uji t-test yang diketahui bahwa diperoleh nilai thitung untuk nilai posttest adalah 4,87 dengan menggunakan taraf signifikansi 5\% atau $=0,05$ dan dengan derajat kebebasan 57, diperoleh hasil $t_{\text {tabel }}$ sebesar 1,67 . Karena thitung $>t_{\text {tabel }}(4,87>1,67)$ maka $\mathrm{H}_{0}$ ditolak dan $\mathrm{H}_{1}$ diterima.

\section{DAFTAR PUSTAKA}

Huda, Miftahul. (2013). Cooperative Learning. Yogyakarta: Pustaka Belajar.

Mafatih dan Bisyri, Ahmad. (2013). Makalah Strategi Belajar Dengan Cara Kooperatif Bidang Studi IPS, (http://media.diknas.go.id, Diakses 11 November 2013).

Purwanto, Ngalim. (2013). Psikologi Pendidikan. Jakarta: PT Remaja Rosdakarya.

Rahayu, Budi Arti. (2011). Penerapan Strategi Pembelajaran The Power Of Two dalam Upaya Peningkatan Hasil Belajar Aqidah Akhlak Siswa Kelas VII 1 MTS Syaroful Millah Penggaron Kidul Semarang. Skripsi. Semarang: Fakultas Tarbiyah Institut Islam Negeri Walisongo.

Sanjaya, Wina. (2009). Strategi Pembelajaran Berorientasi Standar Proses Pendidikan. Jakarta: Kencana Prenada Media Grup. 
Sugiyono. (2011). Metode Penelitian Kuantitatif, Kualitatif dan $R \& D$. Cet. XIII. Bandung: CV Alfabeta.

Sugiyono. (2013). Metode Penelitian Pendidikan. Cet.XVI. Bandung: Alfabeta.

Suryabrata, Sumadi. (2009). Metode Penelitian. Jakarta: Rajawali Pers.

Yahya. (2012). Penerapan Model Pembelajaran Kooperatif Tipe Think Pair Share (TPS) dalam Meningkatkan Prestasi Belajar Siswa Pada Materi Ciri-Ciri Makhluk Hidup di SMP Negeri 2 Sakti Kabupaten Pidie. Jurnal (online), Volume 13 Nomor 2, (http://www.serambimekkah.ac.id/download/September-2012.pdf., Diakses 2 Mei 2016). 